FILOZOFIA

Roč. 77, 2022, č. 1

DOI: https://doi.org/10.31577/filozofia.2022.77.1.3

\title{
KRITIKA POJMU LUUSKEJ DÔSTOJNOSTI V KONCEPCII SUZY KILLMISTEROVEJ
}

MARTIN TURČAN, Univerzita Komenského v Bratislave, Právnická fakulta, Katedra teórie práva a filozofie práva, Bratislava, SR

TURČAN, M.: Critique of the Concept of Human Dignity in the Conception of Suzy Killmister

FILOZOFIA, 77, 2022, No 1, pp. $36-47$

\begin{abstract}
The paper deals with Suzy Killmister's approach to the concept of human dignity. The author analyzes her view and argues that the concept offered by her is relativistic to the degree in which the idea of universal human rights is susceptible to collapse, even though she seems to wish to uphold it. The author points to several problems in Killmister's theory and concludes that, besides its inspiring nature, there is not a safe enough ground for its endorsement.
\end{abstract}

Keywords: Human dignity - Personal dignity - Social dignity - Status dignity - Human rights

\section{Úvod}

Kontroverznost' pojmu l'udská dôstojnost' v súčasnej filozofii netreba osobitne ozrejmovat'. Posledné roky či desat'ročia boli plodné na diskusie tohto druhu. ${ }^{1}$ Ako je známe, praktický význam daného pojmu tkvie najmä v skutočnosti, že sa stal základom modernej koncepcie l’udských práv (Menke 2017, 171 a n.; Palovičová 2017, 68; prípadne Svák 2011, 21 - 22). Okrem iného to znamená, že zachovanie, zmena či opustenie existujúcej idey univerzálnych l'udských práv závisí (aj) od toho, ako sa pojem l'udskej dôstojnosti uchopí a zdôvodní.

K významným autorom, ktorí sa dnes pokúšajú ideu univerzálnych l’udských práv v zásade udržat', avšak revidujú pojem l'udská dôstojnost' - kl'účový pojem, od ktorého sa táto idea odvodzuje - patrí austrálska filozofka Suzy Killmisterová. ${ }^{2}$ Prináša vlastné chápanie pojmu l'udská dôstojnost', ktoré opúšt’a klasické metafyzické

\footnotetext{
${ }^{1}$ Problematika bola v ostatných rokoch tematizovaná aj na stránkach časopisu Filozofia (pozri napríklad Foltin 2021, Sedová 2021, Lohman 2018, prípadne predtým Gluchman 2004, Nemčeková 2001). ${ }^{2}$ Suzy Killmister je profesorka filozofie na austrálskej Monash University. Je autorkou množstva výstupov z oblasti sociálnej filozofie, politickej filozofie a etiky; osobitne možno zmienit', že je napríklad spoluautorkou publikácie The Oxford Handbook of Philosophy and Disability (2018), v rámci ktorej spracovala práve kapitolu o dôstojnosti a úcte.
} 
východiská (čiže nevychádza $\mathrm{z}$ fundacionalizmu a odmieta ideu vrodenej dôstojnosti), no je presvedčená, že toto chápanie stále dokáže plnit’ funkciu zdôvodnenia l'udských práv. ${ }^{3}$

Predmetom tohto príspevku je kritická analýza Killmisterovej koncepcie. Jeho štruktúra je jednoduchá: (1) Killmisterovej chápanie pojmu l'udskej dôstojnosti najskôr stručne predstavím a (2) následne ho v stati „Diskusia“ podrobím kritike. Budem argumentovat', že ide o koncepciu, ktorá pojem univerzálne l'udské práva nechráni tak, ako by si to azda sama autorka priala, respektíve že jej koncepcia ochranu l'udských práv filozoficky ohrozuje, a tiež že trpí určitým pojmovým „napätím“. Svoje tvrdenia nakoniec stručne zhrniem v závere.

\section{Killmisterovej pojem dôstojnosti}

Ako je známe, pojem l'udská dôstojnost' sa v etike i práve používa (prinajmenšom) v dvoch rámcovo odlišných významoch: (1) ako vlastný pojem a (2) ako ašpiračný pojem $^{4}$ (Schroeder 2012, 324 - 332; Schroeder, Bani-Sadr 2017, 9 - 64; Vacura 2020, 520 - 522; Seiler, Seilerová 2010, 28; Fábry 2018, 265 a 274). Vlastný pojem sa tradične vzt'ahuje k človeku ako takému a je základom jeho neodňatel'ných, nescudzitel'ných, nezrušitel'ných a nepremlčatel'ných práv. Dôstojnost' v tomto zmysle teda človek nemôže stratit'. Naproti tomu ašpiračný pojem sa týka akýchsi vonkajších prejavov hodnoty človeka, úcty voči nemu, a to (aj) v jeho spoločensko-kultúrnom kontexte. Predstavuje taký druh dôstojnosti, ktorý môže u rozličných l’udí existovat' v rozličnej miere a o ktorý možno človeka i pripravit'. Ked' napríklad povieme, že človeku, s ktorým sa zaobchádzalo neslušne, alebo dokonca kruto, že bola pošliapaná, upretá či vzatá jeho dôstojnost', máme namysli tento druhý druh l'udskej dôstojnosti.

Z uvedenej dichotómie vychádza vo svojich úvahách aj Suzy Killmisterová. Nóvum jej prístupu má však spočívat' $v$ tom, že na zdôvodnenie univerzálnych l'udských práv, a zároveň na vyjadrenie získatel'nej a odňatel'nej dôstojnosti podl'a nej v skutočnosti postačuje jediný pojem. Fundacionalistické chápanie l'udskej dôstojnosti pokladá za neudržatel'né, je však presvedčená, že to neznamená, že by sme mali univerzálny charakter l'udských práv v dnešnom chápaní „hodit' do koša“. Tvrdí, že ho možno založit' na odlišnom pojme, ktorý predkladá.

Killmisterová začína poukázaním na tri požiadavky (angl. desiderata), ktoré má pojem l'udskej dôstojnosti spĺnat' - na požiadavku univerzality (universalist desideratum), požiadavku zranitel'nosti (vulnerability desideratum) a požiadavku úspechu

\footnotetext{
${ }^{3}$ Už dlhšie poukazuje na skutočnost', že idea l'udskej dôstojnosti je užitočným konceptom, ktorý nie je vhodné opúšt’at' (pozri napríklad Killmister 2010).

${ }^{4} \mathrm{O}$ ašpiračnom pojme l'udskej dôstojnosti tu pojednávam $\mathrm{v}$ širokom význame a nevzt'ahujem ho len na otázky cti (postavenia v hierarchickej štruktúre spoločnosti), ako sa to niekedy robí.
} 
(achievement desideratum). Prvá požiadavka vyjadruje skutočnost', že človeka si vážime ako l'udskú bytost'. Čiže ide o požiadavku, aby každá l'udská bytost' bola objektom našej úcty. Druhá požiadavka sa týka možnosti porušenia či straty dôstojnosti. O ludskej dôstojnosti teda musíme byt' schopní hovorit' aj ako o čomsi, čo možno stratit'. Takýto prežitok l’udia zakúšajú najmä v extrémnych situáciách (napríklad v koncentračných táboroch, pri mučení, v prílišnej biede a pod.), ked' mnohí z nich povedia, že ich dôstojnost' im bola vzatá. Tretia požiadavka sa týka zohl'adnenia nášho rozlišovania l'udí na dôstojnejších a menej dôstojných s ohl'adom na ich pozíciu v spoločnosti, na ich zásluhy a cnosti. Ide teda o požiadavku brat' vážne prínos človeka pre spoločnost' a jeho schopnost' byt' vzorom. $Z$ tohto hl'adiska môže dôstojnost' existovat' u rôznych l'udí v rozličnej miere $(2017,2064-2065) .^{5}$

Možno povedat', že požiadavka univerzálnosti zodpovedá vlastnému pojmu l'udskej dôstojnosti, zatial' čo požiadavky zranitel'nosti a úspechu zodpovedajú ašpiračnému pojmu. Ako som však už naznačil, Killmisterová sa pokúša predostriet' takú koncepciu pojmu l'udskej dôstojnosti, ktorá pokryje všetky tri požiadavky zároveň, pričom $\mathrm{v}$ jadre nebude metafyzická. Námietku, že takáto snaha je zbytočná, pretože $\mathrm{v}$ troch uvedených požiadavkách ide prinajmenšom o dva rôzne pojmy l'udskej dôstojnosti, pokladá Killmisterová za unáhlenú, nezohl’adňujúcu ,žitú skúsenost' tých, čo bedákajú, že ich dôstojnost’ bola poškodená, či dokonca zničená“ $(2017,2065)$. Podotýka že ,tým by sme stratili jednu cennú cestu k porozumeniu povahy takýchto zranení. Ak by bolo v skutočnosti možné rozvinút' koncepciu dôstojnosti, ktorá by spĺn̆ala obe požiadavky [t. j. požiadavku univerzality i požiadavku zranitel'nosti; pozn. autora], mali by sme dobrý dôvod spravit’ tak,“(2017, 2065 - 2066). Pokial' ide o požiadavku úspechu, Killmisterová súhlasí s tým, že táto je menej významná ako prvé dve, avšak podl’a nej „má morálnu dôležitost', ked’že sa používa ako meradlo l'udských cností. Ak by bolo možné rozvinút' koncepciu, ktorá by zohl'adňovala aj požiadavku úspechu popri dvoch d’alších, potom by šlo o dôležité plus v prospech tejto koncepcie,“ dodáva $(2017,2066)$.

Autorka podrobuje kritike dominantné prístupy, ktoré sa zakladajú na ideách ludskej autonómie a prirodzenosti (Killmister 2017, 2066 - 2070; Killmister 2016, 1090 - 1091; pozri tiež Killmister 2020, 6 - 9, 16 a n.). Problémy s autonómiou ako

\footnotetext{
${ }^{5} \mathrm{Na}$ inom mieste Killmisterová používa odlišné výrazy - respect desideratum, fragility desideratum a variability desideratum $(2020,13$ - 15). Posledné dva zodpovedajú požiadavke zranitel'nosti a požiadavke úspechu. Respect desideratum vyjadruje skutočnost', že l'udská dôstojnost' je určitým štandardom, respektíve spája sa s určitým štandardom - normou, ktorá káže úctu k človeku. Explicitné pridanie tejto požiadavky v jej monografii Contours of Dignity z roku 2020 však na danej koncepcii nič nemení, pretože s ním Killmisterová implicitne počítala už predtým. Autorka na tom istom mieste rovnako apriórne predpokladá požiadavku univerzálnosti $(2020,13$ - 14), takže táto požiadavka sa ani tu z jej koncepcie nestráca.
} 
zdrojom l'udskej dôstojnosti, rozpracovaným najmä v kantovskej tradícii, sú všeobecne známe - toto kritérium vylučuje z okruhu bytostí s dôstojnost'ou niektorých ludí (duševne postihnutých, novorodencov atd'.), čím vlastne nespíňa požiadavku univerzality (Regan 2004, 183 - 185). Apel na ideu l'udskej prirodzenosti (podstaty) je zas kritizovatel'ný ako „druhistický“ - prečo by mala byt' naša dôstojnost' determinovaná t’ažiskovo či výlučne našou DNA? (Singer, 2008, 39 a n.) Killmisterová prichádza s iným pojmom l'udskej dôstojnosti, ktorú vysvetl'uje ako spôsobilost' dodržat' či porušit' osobné alebo spoločenské štandardy, a to vlastným konaním alebo i konaním iného voči nám $(2017,2073$ a n.) a v súvislosti s tým zároveň ako spôsobilost' byt'objektom úcty (2020, 33 a 58).

Život podla osobných štandardov samozrejme úzko súvisí s autonómiou (a tým i so sebaúctou). Osobné štandardy však podla Killmisterovej nie sú jediným kritériom, prostredníctvom ktorých možno konštituovat' ideu l'udskej dôstojnosti. Tvrdí, že zásadnú rolu tu zohrávajú predovšetkým štandardy spoločnosti, do ktorej človek patrí, teda normy, ktoré spoločnost' pokladá za záväzné pre svojich členov. Podotýka pritom, že nie všetky spoločenské normy sú relevantné pre pojem dôstojnosti. Podstatné sú len tie, ktorých porušenie spoločnost’ vníma ako hanebné (shameful) (2017, 2071).

Z uvedeného vyplýva, že Killmisterová rozlišuje osobnú dôstojnost' (ktorá spočíva v sebaúcte a je založená na zachovávaní a rešpekte osobných hodnôt) a spoločenskú dôstojnost' (spojenú so spoločenskými hodnotami a normami). ${ }^{6}$ Hovorí tiež o statusovej dôstojnosti, ktorá súvisí s uznaním (recognition) človeka ako subjektu hodného úcty vzhl'adom na jeho príslušnost' k určitej sociálnej (t. j. spoločnost'ou rozpoznanej) kategórii $(2020,33)$. Voči osobnej dôstojnosti človeka konáme, ked’ nerešpektujeme jeho osobné hodnoty, napríklad ked' ho vedieme či tlačíme k tomu, aby sa zachoval v rozpore s vlastnými etickými normami. Voči spoločenskej dôstojnosti človeka konáme, ked' nerešpektujeme spoločenské normy, napríklad ked' ho nútime konat' $\mathrm{v}$ rozpore so spoločenskými predstavami o morálke. Voči statusovej dôstojnosti človeka konáme vtedy, ked’ sa k nemu nesprávame ako k bytosti, ktorá je hodná úcty, ked' ho znevažujeme a nerešpektujeme ako subjekt (2020, 39 a n.). „Napríklad prekročit' bezdomovca, akoby tam ani nebol, znamená zlyhat' v priznaní mu jednej z najzákladnejších podôb úcty,“ uvádza Killmisterová v súvislosti so statusovou dôstojnost'ou $(2020,58)$. Je vhodné podotknút', že statusová dôstojnost' je v tejto koncepcii nerozlučne spojená so sociálnou dôstojnost'ou $(2017,2076)$ a že Killmisterová chápe l'udskú dôstojnost', ktorá má byt' základom l’udských práv, ako sociálnu, spoločenskú

\footnotetext{
${ }^{6} \mathrm{Na}$ inom mieste uvádza: „Porušovanie osobnej dôstojnosti je teda primárne poškodením subjektívnosti. Porušovanie spoločenskej dôstojnosti je, naopak, predovšetkým poškodením spoločenského postavenia obete" (Killmister 2016, 1097).
} 
kategóriu. ${ }^{7}$ Ako vyplýva zo všetkého doteraz načrtnutého, l'udská dôstojnost' podl'a nej nie je človeku vrodená, ale je nadobudnutá, udelená (conferred). Človek ju získava na základe postoja spoločnosti (práve preto sa d'alej v príspevku sústredím najmä na Killmisterovej chápanie l'udskej dôstojnosti ako spoločenskej a statusovej dôstojnosti, ked’že tieto pojmy u nej predstavujú východisko idey l’udských práv).

Pre lepšiu predstavu uvádza príklad duševne postihnutej mladej ženy menom Nora, ktorá nie je schopná chápat' spoločenské normy a pri ich porušení necíti žiadnu hanbu. Jedného dňa ju skupina mladých mužov prehovorí, aby sa vyzliekla, nafotí ju v nelichotivých polohách a jej fotky rozšíri na sociálnej sieti. To, čo sa stalo, nijakým spôsobom nenaráža na Norinu osobnú dôstojnost', pretože štandardy, ktoré bola navedená prekročit', nie sú jej vlastné. Dochádza však k porušeniu jej spoločenskej dôstojnosti (a tým, že sa mladí muži svojím konaním Nore vysmievajú a že je nimi zneuctená, čo uzná každý rozumný člen spoločnosti, hoci ona o tom nevie, dochádza samozrejme i k porušeniu jej statusovej dôstojnosti). Dotyční muži ju cielene ponížili tým, že ju primäli k prekročeniu spoločenských noriem sexuálneho správania. „Je dôležité, že ich snaha o poníženie má zmysel jedine, ak je Nora uznaná za subjekt, na ktorý sa vzt'ahujú normy, ku ktorých porušeniu dochádza. Podstatné je, že mladí muži si v tomto príklade volia sexuálne poníženie mladej ženy, a nie napríklad neživého predmetu, akým je kameň. Je nezmyselné snažit' sa poniźžit kamene, pretože neexistujú štandardy, ktoré by mohol kameň porušit'. Naopak, mladé ženy, hoci aj duševne postihnuté, môžu porušit' mnoho spoločenských noriem, a je to práve táto (nesporne pol’utovaniahodná) skutočnost' [...], ktorá je $\mathrm{v}$ pozadí správania dotyčných mladých mužov. [...] Takže Nora zjavne má dôstojnost', pretože podlieha spoločenským štandardom svojej spoločnosti (inak by snaha ponížit' ju nedávala žiadny zmysel). A jej dôstojnost' je zjavne poškodená, pretože je dotlačená prestúpit' tieto štandardy (čo je

\footnotetext{
${ }^{7}$ Pokial' ide o spôsoby konania proti l'udskej dôstojnosti, Killmisterová rozlišuje porušenie (violation), hatenie (frustration) a zničenie (destruction) l'udskej dôstojnosti a približuje spôsoby takýchto konaní vo vzt'ahu k osobnej, spoločenskej i statusovej dôstojnosti. Príkladom porušenia osobnej a spoločenskej dôstojnosti môžu byt' rôzne druhy sexuálneho znevažovania pri ktorých dochádza k porušeniu osobných či spoločenských noriem sexuálnej mravnosti $(2020,49)$. Príkladom porušenia statusovej dôstojnosti môže byt' už zmienené bezohl'adné ignorovanie úbožiaka ležiaceho na zemi, akoby tam ani nebol, teda situácia, ked' človek nie je uznaný za objekt úcty $(2020,58)$. Naša osobná dôstojnost' je podl'a Killmisterovej hatená vtedy, ked' sa nám bráni v osobnom rozvoji (2020, 86), spoločenská dôstojnost' zas vtedy, ked' nám druhí bránia presadzovat' normy, ktoré sú spoločnost'ou pokladané za zušl'acht'ujúce $(2020,95)$ a hatenie statusovej dôstojnosti popisuje ako situáciu, ked' nám ostatní neuznajú žiadny priestor v určitej oblasti života $(2020,125)$. Zničenie našej osobnej dôstojnosti nastáva, ked' sa viac nie sme schopní považovat' za bytost' hodnú úcty $(2020,86)$, k zničeniu našej spoločenskej dôstojnosti dochádza, ked' na nás už takto nenazerajú ostatní členovia spoločnosti $(2020,98)$ a zničením našej statusovej dôstojnosti je napokon naše vylúčenie (exkomunikácia) zo spoločnosti (2020, 68 a 126).
} 
celý zmysel poníženia)“(Killmister 2017, 2074; k tomuto príkladu pozri tiež Killmister 2020, 31 - 32).

Takéto chápanie je podla Killmisterovej spôsobilé uspokojit' všetky tri požiadavky kladené na pojem l'udskej dôstojnosti. Skutočnost', že Nora bola objektívne ponížená, ukazuje na poškodenie jej dôstojnosti (požiadavka zranitel'nosti). Skutočnost', že spoločnost' pokladá Noru za adresáta svojich noriem, i ked' nie je plne rozvinutým (duševne zdravým) človekom, ukazuje na univerzálny charakter l'udskej dôstojnosti (požiadavka univerzality). A do tretice, je pomerne zrejmé, že ak je dôstojnost' spoločenskou kategóriou, tak je v princípe možné aplikovat' na ňu aj požiadavku úspechu (v závislosti od rôznej úrovne rešpektu spoločenských noriem môžu ludia dosahovat' viac či menej dôstojnosti) (2017, 2075 a 2080).

Hoci rôzne spoločnosti môžu mat' rôzne štandardy a môžu ich vzt'ahovat' na rôzne subjekty, Killmisterová tvrdí, že existuje jeden druh spoločenstva, ktoré má univerzálny rozmer. Ide o spoločenstvo všetkých ludských bytostí, o l'udskú spoločnost': „Tvrdím, že sociálnym faktom nášho dnešného sveta je, že sme vytvorili globálne spoločenstvo l'udských bytostí, a tým sme vytvorili l'udskú dôstojnost'. Hoci hranicami tohto l'udského spoločenstva sú hranice druhu, nie je to druhová príslušnost' per $s e$, kvôli ktorej majú l'udské bytosti dôstojnost' a právo na úctu. [...] Povedané o čosi dôraznejšie: niet nič výnimočného na druhovej hranici ,ludská bytost" popri význame, ktorým sme ho zafarbili. Každopádne, každá l’udská bytost' má právo na úctu ako l'udská bytost', pretože toto je čast' významu, ktorý bol vytvorený pre l'udské spoločenstvo“ $(2017,2078)$. Na inom mieste podotýka, že l'udská dôstojnost' nie je „vrodená vlastnost' osôb, ktorá zakotvuje alebo zhŕňa ich hodnotu a z ktorej sa l'udské práva odvodzujú. [...] L'udské práva teda možno pokladat' za mechanizmy, ktoré sme vytvorili na presadenie l'udskej dôstojnosti. L'udská dôstojnost' teda slúži ako základ l'udských práv nie v tom zmysle, že by sme obsah l'udských práv mohli odvodit' priamo z pojmu l'udskej dôstojnosti, ale skôr v tom zmysle, že l'udská dôstojnost' má explanačnú prednost' pred l'udskými právami a l'udské práva slúžia na ochranu l’udskej dôstojnosti. Ťažisková myšlienka znie takto: rovnako ako aristokratická spoločnost' dospela k uznaniu štandardov dôstojnosti pre všetkých svojich členov, ako bolo napríklad právo byt' oslovovaný určitým spôsobom či očakávat' zloženie klobúka vo svojej prítomnosti, tak globálne spoločenstvo dospelo k uznaniu štandardov dôstojnosti pre všetkých l'udí. Inými slovami, vytvorili sme skupinu ,človek‘ ako spoločenský druh, naplnili ju významom a hodnotou a rozšírili ju na biologickú kategóriu ,človek““ (2016, 1098 - 1099).

Killmisterová teda predstavuje l'udskú dôstojnost' ako sociálny konštrukt, ako čosi, čo spoločnost' priznáva svojim členom: „L'udská dôstojnost' sa v mojom ponímaní týka statusu, ktorý si navzájom udelujeme“ $(2020,148)$. Je si vedomá kontroverznosti 
svojho tvrdenia, no je presvedčená, že takýmto pojmom l'udskej dôstojnosti možno zdôvodnit' univerzálny charakter l'udských práv. Uzatvára: „Hoci takýto spôsob nazerania na dôstojnost' každého neuspokojí - zvlášt' neuspokojí tých, ktorí neprestávajú hl'adat' nejakú vrodenú črtu osôb, z ktorej môžeme odvodit' všetky l'udské práva dúfam, že ponúka nový a potenciálne produktívny pohl’ad na pojem dôstojnosti i na teóriu l'udských práv. Nepochybne, z tejto úvahy vyplýva, že l'udské práva sú náhodnou črtou nášho spoločenského prostredia a mnohí sa zháčia nad touto náhodnostou. Umožňuje nám to však vidiet' vel'kost' úspechu, ktorým l'udská dôstojnost' a l'udské práva sú a na ktorý máme byt' právom hrdí, ale pokial' ide o ich ochranu, nemôžeme si dovolit' nechat' sa ukolísat' spokojnost'ou“" $(2016,1101)$.

\section{Diskusia}

Killmisterovej prístup sa javí ako relativistický. Voči pomyselnej námietke o odlišnosti kultúr, ktorá svedčí proti požiadavke univerzality l'udskej dôstojnosti, sa síce Killmisterová explicitne bráni odkazom na univerzálne l’udské spoločenstvo, ktoré $\mathrm{v}$ dvadsiatom storočí prijalo ideu ludskej dôstojnosti a univerzálnych l'udských práv. Nazdávam sa však, že takáto obrana l'udskej dôstojnosti a l’udských práv ostáva problematická. Už táto téza je totiž istým spôsobom kontroverzná a hoci ju akceptujeme, ostane nám problém relatívnosti hodnôt globálneho spoločenstva ako takého. Z koncepcie Suzy Killmisterovej totiž v podstate vyplýva, že akékol'vek (dostatočne významné) hodnotové zmeny v globálnom spoločenstve môžu mat' teoreticky za následok legitímne zmeny v pojme l'udskej dôstojnosti a v koncepcii l'udských práv, respektíve že existujúca podoba ludských práv tu vôbec nemusela byt', ani tu nemusí byt' $\mathrm{v}$ budúcnosti a bude to tak $\mathrm{v}$ poriadku (je kontingentná, a teda len relatívne legitímna). Sama uvádza, že úcta voči l’udským bytostiam ,je skôr sociálnou normou, ktorú sme vytvorili a ktorá sa môže v budúcnosti zmenit', než nezmenitel'ným morálnym faktom“ $(2017,2079)$.

Predstavme si teda napríklad hypotetickú situáciu, v ktorej by sa Adolfovi Hitlerovi podarilo dobyt' svet a presadit' $\mathrm{v}$ ňom svoju doktrínu nadradenosti árijskej rasy. V takomto globálnom spoločenstve by platila téza, že skutočnú l'udskú dôstojnost' majú iba árijci (ktorí sa rozširujú do nových „životných priestorov“, pričom ich je už, povedzme, výrazne viac ako všetkých ostatných). Ostatní sú len „,podludia“, čo platí najmä o duševne postihnutých, ${ }^{8}$ akou je vo vyššie uvedenom príklade Nora. Čo môže Killmisterová takejto idei „'udskej dôstojnosti“ a z nej odvodenej koncepcii „l'udských práv“" vlastne vytknút? Námietku, že reč nemá byt' o alternatívnej histórii, ale o aktuálnej, v ktorej sa presadila práve dnešná koncepcia univerzálnych l'udských práv, možno zodpovedat' poukázaním na možnost' podobnej zmeny nášho aktuálneho

${ }^{8}$ Netreba pripomínat' historický nacistický postoj k takýmto l'ud’om. 
sveta v budúcnosti. Hoci sa viac vôbec nemusia zopakovat' hrôzy nacizmu, nemožno vylúčit' napríklad vznik takej globálnej komunity, ktorá bude popierat' niektorú z aktuálne zásadných l'udskoprávnych hodnôt (napríklad vo vzt’ahu k určitej názorovej menšine), pričom na takomto presvedčení bude v princípe panovat' ,pomyslená globálna zhoda“. Problém teda môže byt' v jadre podobný ako vo vyššie uvedenom kontrafaktuálnom príklade s Hitlerom. Voči hitlerovskému príkladu navyše neobstojí ani tvrdenie, že Killmisterová by mohla dané nacistické chápanie „l'udskej dôstojnosti“ kritizovat' práve pre nesplnenie požiadavky univerzálnosti (universalist desideratum), $\mathrm{s}$ ktorou jej teória počíta. Teda že $\mathrm{v}$ duchu jej koncepcie by hitlerovské chápanie pojmu l'udskej dôstojnosti bolo vlastne nelegitímne. Sama totiž uvádza, že univerzálnost' l'udskej dôstojnosti a l'udských práv (teda ich vztiahnutie na každú bytost' l'udského druhu), je vecou rozhodnutia l’udského spoločenstva, ktoré „vytvorilo skupinu ,človek' ako spoločenský druh, naplnilo ju významom a hodnotou a rozšírilo ju na biologickú kategóriu ,človek““ $(2016,1099)$. Toto spoločenstvo teda môže svoj prístup v budúcnosti vlastným rozhodnutím zmenit' a požiadavku univerzálnosti z pojmu l'udskej dôstojnosti vypustit'. Aký dôvod by mu v tom bránil? Zdá sa, že zmysel vol'by troch uvedených požiadaviek (univerzalita, porušitel'nost' a úspech) Killmisterovou je skôr fenomenologický a „aktualizačný“ (ide o akúsi fenomenologickú analýzu pojmu l'udskej dôstojnosti v kontexte dneška). Tým sa však možno prinajlepšom snažit' filozoficky vysvetlit’ súčasnú medzinárodnú l'udskoprávnu prax (prípadne „vylepšit“ jej aktuálne vysvetlenie). Skutočná kritická funkcia a normatívna sila pojmu l'udská dôstojnost' sa tým každopádne oslabuje, či priamo stráca.

Bez problémov azda nie je ani pojem spoločenstvo všetkých l'udských bytostí, na ktorý Killmisterová odkazuje pri definovaní univerzálnej l'udskej dôstojnosti ako spoločenskej a statusovej dôstojnosti. Možno sa pýtat', či takéto „normotvorné“ spoločenstvo všetkých l’udských bytostí existuje. Ak poukážeme na OSN a napríklad na ním prijatú Všeobecnú deklaráciu l’udských práv, ktorá sa už v preambule hlási k idei l'udskej dôstojnosti (ako to, zdá sa, chápe i sama Killmisterová), vynorí sa otázka o vzt’ahu medzi pojmom l'udská dôstojnost' a politikou. Táto otázka je zásadná. V aktuálnom svete by sme našli štáty, ktoré podpísali Všeobecnú deklaráciu l'udských práv, no neujalo sa v nich všeobecné presvedčenie o takom pojme l'udskej dôstojnosti, o akom hovorí daná deklarácia. A čo keby boli napríklad všetky štáty na svete diktatúrami (či už diktatúrami jednotlivca, alebo diktatúrami väčšiny) a ich zástupcovia by na spoločnom zhromaždení prijali dokument vymedzujúci „l’udské práva“? I to by bolo v poriadku, ak má byt' l'udská dôstojnost' len spoločensko-politickým konceptom 
(čiže, ak máme akceptovat' Killmisterovej politickú ${ }^{9}$ koncepciu daného pojmu)? ${ }^{10}$ Zdá sa, že koncepcia univerzálnych l’udských práv jednoducho je a musí byt' etickou koncepciou, vychádzajúcou z premís morálneho objektivizmu, nech už ide o akúkol'vek morálno-objektivistickú teóriu. Inak stráca presvedčivost’, alebo je dokonca vnútorne rozporná.

Ako sme videli, Killmisterová sama naznačuje, že aktuálny svet, v ktorom vládne idea univerzálnych l'udských práv, založených na pojme l'udská dôstojnost', je lepši ako svety, ktoré tu boli v predchádzajúcich dobách. V akom zmysle je však tento svet lepší? Aby jej vyjadrenie, že rozpoznanie idey l'udskej dôstojnosti a univerzálnych práv človeka ,je úspechom, na ktorý máme byt' právom hrdí“ a ktorý sa nemáme prestat' snažit' chránit' $(2016,1101)$, malo zmysel, náš aktuálny svet musí byt' (aj) morálne lepši (morálne prijatel'nejší) ako tie predchádzajúce, a to objektivne. Inak konštatovanie o potrebe oprávnenej hrdosti a ochrany stráca obsah. Ak teda Killmisterová vychádza z nejakých morálno-objektivistických východísk, je potrebné, aby túto skutočnost' do svojej koncepcie pojmu l'udskej dôstojnosti zahrnula (trebárs aspoň tak, ako sa o to snažia niektorí utilitaristi, ktorí síce l'udskú dôstojnost' pokladajú tiež len za konštrukt, avšak za užitočný konštrukt, ktorý sa z hl'adiska maximalizácie úžitku musí vyznačovat' určitou stabilitou). ${ }^{11}$

Dovolím si povedat', že Killmisterovej koncepcia má napokon svoje úskalie aj z hl'adiska úsilia zastrešit' uvedené tri požiadavky (teda požiadavku univerzality, požiadavku porušitel'nosti a požiadavku úspechu) pod jediný pojem l’udskej dôstojnosti. Je síce pravda, že ak za zdôvodnenie l'udskej dôstojnosti pokladáme rozhodnutie spoločenstva (s ohl'adom na vol'bu štandardov správania človeka a správania iných voči človeku, resp. úcty voči človeku, potom možno všetky tri požiadavky v istom (obmedzenom) zmysle skryt' pod jednu strechu. Teda platí, že „neodňatel'ná“ i porušitel'ná dôstojnost' sú iba výsledkom postoja spoločnosti voči jednotlivcovi, a nie je to tak, že

\footnotetext{
${ }^{9}$ Nejde pritom, samozrejme, o politickú teóriu ako takú, v jadre ktorej by bola idea l'udskej dôstojnosti, ale o teóriu l'udskej dôstojnosti, ktorá chápe l'udskú dôstojnost' ako politicky determinovanú. Killmisterová sama uvádza, že jej ciel'om je „skôr preskúmat' zmysel a význam dôstojnosti, než rozpracovat' súhrnnú morálnu alebo politickú teóriu dôstojnosti““ $(2020,4)$.

${ }^{10}$ Dalo by sa namietnut', že diktatúry jednotlivcov či úzkych skupín nereprezentujú vôl'u svojich občanov. Aj ony však dokážu aspoň čiastočne indoktrinovat' predstavy širokých más. I v prípade odmietnutia argumentu diktatúrou jednotlivca či malej skupiny pritom ostáva zachovaný argument diktatúrou väčšiny: Čo keby výrazná väčšina obyvatel'ov sveta - či už z presvedčenia, alebo len z kolaborantstva - dospela k záveru, že určitá skupina l'udí dôstojnost' nemá (napr. už spomínaný príklad hypotetického vít’azstva fašizmu, vd’aka porážke ktorého sa predsa dnes v medzinárodnom spoločenstve o l'udskej dôstojnosti hovorí)?

${ }^{11} \mathrm{~K}$ vzt’ahu utilitarizmu a l'udských práv pozri napríklad Hapla (2020). Hapla sa pokúša o argumentáciu, že človek môže byt' utilitaristom a zároveň vyznávačom idey univerzálnych l'udských práv. Podmienkou je však podl'a neho akceptovat' l'udské práva ako legálne, nie morálne práva, a akceptovat' východisko utilitarizmu pravidiel, nie utilitarizmu činu.
} 
by prvá pramenila z jeho podstaty či z nejakých iných metafyzických predpokladov, zatial' čo druhá by bola, povedzme, výlučne kultúrno-spoločensky podmienená (napríklad otázka úcty k sudcom, král’om a pod.). Avšak ani tak sa pojmový rozdiel medzi zdôvodnením l'udských práv a ašpiráciou na určité vonkajšie manifestácie l'udskej hodnoty v skutočnosti neodstráni. Stále totiž platí, že ked' hovoríme o dôstojnosti ako o základe l'udských práv (hoci nemusí íst' o fundacionalistickú koncepciu, ale môže íst' pokojne o koncepciu, akú ponúka Killmisterová), a ked' o nej hovoríme ako o čomsi, na čo má človek právo, zo sémantického hl'adiska hovoríme o dvoch rôznych veciach. Ide teda o dva rôzne pojmy. Ani argument, že potrebujeme len jeden pojem, aby sme „nestratili jednu cennú cestu k porozumeniu povahe zraneni“ l'udí, ktorých „žitá skúsenost‘“ je spojená s nárekom, ,že ich dôstojnost' bola poškodená, či dokonca zničená..." (Killmister 2017, 2065 - 2066), na tom nič nezmení. Tento Killmisterovej argument sa navyše môže týkat' len osobnej dôstojnosti, ktorá pre zdôvodnenie l'udských práv nie je ani v jej koncepcii určujúca. ${ }^{12}$ Rozhodujúca je pre ňu predsa spoločenská, respektíve statusová dôstojnost' človeka. K získaniu odpovede na otázku (ne)odňatel'nosti dôstojnosti, ktorá má byt' základom l'udských práv, subjektívne l'udské prežívanie jej straty (presvedčenie, že nás spoločnost' odvrhla, alebo že na nás celý svet zabudol) nijako neprispieva a problém treba skúmat' iným spôsobom. Aj ked' túto dôstojnost' nevymedzíme ako vrodenú, ale len ako spoločensky determinovanú, na fakte, že spoločnost' sa rozhodla alebo naopak nerozhodla nejakému človeku ju odňat', jeho osobné vnímanie nič nezmení, ani ho nutne nedokazuje (napríklad mučený človek môže nadobudnút' dojem, že jeho spoločnost', ktorá takémuto činu nezabránila, ním opovrhuje; vôbec to však nemusí byt' pravda).

12 Pričom aj v súvislosti s osobnou dôstojnost'ou sa možno pýtat', či l'udské presvedčenie o strate vlastnej dôstojnosti (stratenie sebaúcty) nie je v kritických situáciách, akou je napríklad mučenie, zakalené bolest'ou natol'ko, že je nesprávne. Raimond Gaita napríklad poukazuje na prípad Jeana Améryho, ktorý prežil brutálne mučenie gestapom, s čím sa nevedel vyrovnat' a napokon, dlho po vojne, spáchal samovraždu (Gaita 2006, 261 - 262). Predstavme si, že dôvodom samovraždy je $\mathrm{v}$ takomto prípade presvedčenie dotyčného, že mučením stratil svoju l'udskú dôstojnost'. Znamená to, že tento človek nemá objektívny morálny nárok voči svojim mučitel’om, aby v mučení nepokračovali, respektíve aby boli za tento čin potrestaní? Ak takýto nárok (právo) má a ak má mat' luudská dôstojnost' pred l'udskými právami explanačnú prednost', tak by dotyčný mal dospiet' k záveru, že svoju dôstojnost' nestratil. Alternatívou je cesta Dorris Schroederovej $(2012,334)$, ktorá poradie vzt'ahu l'udskej dôstojnosti a l'udských práv obracia. Ako tretia možnost' nám ostane číry morálny relativizmus (resp. nihilizmus), ktorý však, ako už som uviedol, ideu l'udských práv zásadne podkopáva. Keby sme teda napriek všetkému chceli mat' len jeden pojem l'udská dôstojnost', tak sa na rozdiel od Killmisterovej domnievam, že by sme mohli nanajvýš povedat', že to, čo sa pácha na človeku, ktorého mučia, je hlbokou urážkou jeho dôstojnosti, nie jej odňatím (čo ona, naopak, odmieta; 2017, 2077 - 2079). 
Dovolím si teda skonštatovat', že hoci koncepcia Suzy Killmisterovej prináša niektoré zaujímavé podnety a diskusiu o l'udskej dôstojnosti vlastným spôsobom obohacuje, z l'udskoprávneho i pojmového hl'adiska sa nejaví ako dostatočne uspokojivá.

\section{Záver}

V príspevku som si všimol, ako pojem l’udská dôstojnost' navrhuje chápat' austrálska filozofka Suzy Killmisterová, ktorá odmieta jeho tradičné metafyzické zdôvodnenie a kriticky hodnotí zdôrazňovanie rozdielu medzi vlastným a ašpiračným pojmom. Tvrdí, že nepotrebujeme dva pojmy l'udskej dôstojnosti, ale vystačíme si s jediným. Metafyzické východiská nahrádza voluntaristickými a pojem l'udská dôstojnost', ktorý je základom l'udských práv, zdôvodňuje rozhodnutím globálneho spoločenstva l'udských bytostí. Možno povedat', že tým ho činí natol'ko relatívnym, že sa vytráca jeho kritická funkcia a schopnost' chránit' ideu univerzálnych l'udských práv za akýchkol'vek okolností, hoci túto ideu Killmisterová zjavne podporuje a pokladá ju za cennú. L’udská dôstojnost' je teda pre ňu determinovaná najmä spoločensky. Ide o sociálny konštrukt, ktorý môže teoreticky podliehat' najrôznejším zmenám. V tomto ohl'ade som sa v príspevku nesnažil priamo vyvrátit' pravdivost' Killmisterovej tvrdení o čisto spoločenskej (politickej) povahe pojmu l'udskej dôstojnosti. Poukázal som len na skutočnost', že ak takéto chápanie uznáme, jeho dôsledky sa dostanú do rozporu s požiadavkami súčasnej l'udskoprávnej praxe, ktoré si sama autorka cení. Otázky možno klást' i v súvislosti s vymedzením univerzálneho spoločenstva všetkých l’udských bytostí, ktoré ma byt' pôvodcom l'udskej dôstojnosti. Killmisterovej koncepcia nie je celkom uspokojivá ani zo sémantického hl’adiska. Spôsob, akým sa usiluje zlúčit' rôzne významy slova l’udská dôstojnost', sa javí ako nadbytočný. Hoci má tento krok za ciel' šlachetné prejavenie súcitu s človekom v t’ažkej existenciálnej situácii utrpenia, v ktorej dotyčný prežíva ,stratu“ či ,zničenie“ vlastnej dôstojnosti, možno sa obávat', že mu v skutočnosti robí „medvediu službu“, ked’že ochranu l'udskej dôstojnosti a idey univerzálnych l'udských práv nezdôvodňuje eticky, ale spoločensko-politicky, čím ju argumentačne oslabuje.

\section{Literatúra}

FÁBRY, B. (2018): Etika a právo, in: Kolektív autorov: Aktuálne otázky teórie práva. Bratislava: Wolters Kluwer, $257-274$.

FOLTIN, M. (2021): Morálno-normatívne zdôvodnenie l’udských práv. Filozofia, 75 (1), 46 - 58. DOI: https://doi.org/10.31577/filozofia.2021.76.1.4

GAITA, R. (2006): Torture: The Lesser Evil? Tijdschrift voor Filosofie, 68 (2), 251 - 278.

GLUCHMAN, V. (2004): L'udská dôstojnost' a neutilitaristická konzekvencialistická etika sociálnych dôsledkov. Filozofia, 59 (7), 502 - 507.

HAPLA, M. (2020): Utilitarismus a lidská práva. Časopis pro právni védu a praxi, 28 (3), 321 336. DOI: https://doi.org/10.5817/CPVP2020-3-1 
KILLMISTER, S. (2010): Dignity: not such a useless concept. Journal of Medical Ethics, 36 (3), $160-164$.

KILLMISTER, S. (2016): Dignity, Torture, and Human Rights. Ethical Theory and Moral Practice, 19 (5), 1087 - 1101. DOI: https://doi.org/10.1007/s10677-016-9725-6

KILLMISTER, S. (2017): Dignity: personal, social, human. Philosophical Studies: An International Journal for Philosophy in the Analytic Tradition, 174 (8), 2063 - 2082. DOI: https://doi.org/10.1007/s11098-016-0788-y

KILLMISTER, S. (2020): Contours of Dignity. Oxford: Oxford University Press.

LOHMANN, G. (2018): K metodologickým otázkam antropológie a „obrazu človeka“ s „ludskou dôstojnost'ou“. Filozofia, 73 (8), 660 - 674.

MENKE, CH. (2017): Ludská dôstojnost'. In: Pollmann, A. - Lohmann, G. (eds.): Ludské práva: interdisciplinárna príručka. Bratislava: Kalligram, 170 - 177.

NEMČEKOVÁ, M. (2001): Poznámky ku konceptu l'udskej dôstojnosti. Filozofia, 56 (5), 300 - 308.

PALOVIČOVÁ, Z. (2017): Ambivalentnost' l'udských práv a neurčitost' ich pojmu z pohl'adu filozofie. Bratislava: Veda.

REGAN, T. (2004): The Case for Animal Rights. Berkeley: University of California.

SEDOVÁ, T. (2021): Fenomén l'udskej dôstojnosti, jej pojem a vzt'ah k l'udským právam. Filozofia, 76 (5), 317 - 332. DOI: https://doi.org/10.31577/filozofia.2021.76.5.1

SEILER, V., SEILEROVÁ, B. (2010): L’udská dôstojnost' - axióma l'udských práv. Bratislava: Vladimír Seiler a Božena Seilerová.

SCHROEDER, D. (2012): Human Rights and Human Dignity: An Appeal to Separate the Conjoined Twins. Ethical Theory and Moral Practice, 15 (3), 323 - 335. DOI https://doi.org/10.1007/s10677-011-9326-3

SCHROEDER, D., BANI-SADR, A.-H. (2017): Dignity in the 21 st Century: Middle East and West. Cham: Springer.

SINGER, P. (2008): Spisy o etickom žiti. Bratislava: Vydavatel'stvo spolku slovenských spisovatel'ov. SVÁK, J. (2011): Ochrana l’udských práv v troch zväzkoch. I. zväzok. Žilina: Eurokódex.

VACURA, M. (2020): Problém založení a legitimace lidských práv. Filozofia, 75 (7), 513 - 526 DOI: https://doi.org/10.31577/filozofia.2020.75.7.1

Martin Turčan

Univerzita Komenského v Bratislave

Právnická fakulta

Katedra teória práva a filozofie práva

Šafárikovo námestie 6

P. O. BOX 313

81000 Bratislava

Slovenská republika

e-mail: martin.turcan@flaw.uniba.sk

ORCID ID: https://orcid.org/0000-0002-4616-6730 